\title{
Action of Growth Hormone on Erythropoiesis: Changes in Red Blood Cell Enzyme Activities in Growth-retarded Patients with and without Growth Hormone Deficiency
}

\author{
N. STAHNKE, ${ }^{(43)}$ AND W. BLUNCK (42) \\ Department of Pediatrics, University of Hamburg, Hamburg, West Germany \\ W. SCHRÖTER \\ Department of Pediatrics, University of Göttingen, Göttingen, West Germany
}

\section{Extract}

Fifteen red cell enzyme activities of growth-retarded patients with and without growth hormone $(\mathrm{GH})$ deficiency were investigated before and after GH administration. The 15 enzymes were Hexokinase, phosphoglucomutase, glucose phosphate isomerase, phosphofructokinase, fructose diphosphate aldolase, glyceraldehyde-3-phosphate dehydrogenase, triosephosphate isomerase, 2,3-diphosphoglycerate mutase, 3-phosphoglycerate kinase, 3-phosphoglycerate mutase, enolase, pyruvate kinase, glycose-6-phosphate dehydrogenase, 6-phosphogluconic dehydrogenase, glutathione reductase.

Sixty-six subjects were studied: 30 normal control subjects (group $N$ ) and 36 patients (aged 5-23 years) with short stature. Complete endocrine evaluation showed 21 (group I) to have $\mathbf{G H}$ deficiency (10 patients with isolated $\mathbf{G H}$ deficiency) and 15 (group II) to have normal hypothalamic and pituitary function except for two patients with a moderate hypothyroidism. Both had been receiving thyroid hormone treatment for a long time before our studies. All 36 patients were treated with $2 \mathrm{mg}$ human growth hormone intramuscularly for 7 days.

Before GH treatment no significant difference was observed between hematologic data in group I (GH deficiency) and group II (no GH deficiency). After GH therapy there was a significant increase in reticulocyte count in both groups of patients with short stature. The mean pretreatment value in group $I$ was $1.294 \% \pm$ 0.084 (SEM); the mean post-treatment value was $2.081 \% \pm 0.287$ (SEM), $P<\mathbf{0 . 0 0 5}$. The mean pretreatment value in group II was $1.0 \% 0.184(\mathrm{SEM})$; the mean post-treatment value was $1.407 \%$ \pm 0.193 (SEM), $P<0.01$.

In group II (no GH devidiency) mean pretreatment erythrocyte enzyme activities were not significantly different from those activities observed in normal control subjects ( group $N$ ). However, in patients who lacked GH, the pretreatment activities of five red cell enzymes (glucose phosphate isomerase, triosephosphate isomerase, glyceraldehyde-3-phosphate dehydrogenase, 2,3-diphosphoglycerate mutase, 3-phosphoglycerate kinase) were significantly decreased before GH administration compared with the values in normal control subjects. The reduction in a further red cell enzyme (3phosphoglycerate mutase) was statistically not significant.

With GH treatment eight red cell enzyme activities showed a significant increase, one of them (hexokinase) significantly rising in both groups of patients. The remaining seven erythrocyte enzymes (3-phosphoglycerate mutase, glucose phosphate isomerase, triosephosphate isomerase, 2,3-diphosphoglycerate mutase, enolase, pyruvate kinase, glucose-6-phosphate dehydrogenase) exhibited significantly elevated activities only in patients lacking GH. In three of these enzymes the increase was significantly above the control value.

Enzyme activities which were significantly decreased before GH administration rose significantly after $\mathbf{G H}$ therapy except for two enzyme activities (3-phosphoglycerate kinase and glyceraldehyde-3phosphate dehydrogenase). The data may suggest the presence of a younger red cell population after $\mathrm{GH}$ administration.

\section{Speculation}

The increase in red cell enzyme activities after GH treatment is supposedly due to stimulation of erythropoiesis by growth hormone. An additional stimulatory effect of GH on nucleated red cell enzyme synthesis is less likely but cannot be definitively excluded.

The strong anabolic action of $\mathrm{GH}$ resulting in increased protein synthesis is well known (15). Enzyme activities elevated because of $\mathrm{GH}$ administration were also reported. In some enzymes this was the result of increased synthesis of the enzyme protein $(16,23)$.

After hypophysectomy, erythropoiesis is impaired in animals and man, resulting in a decreased number of nucleated erythroid cells in the bone marrow and in a reduced red cell volume $(3,8,13$, $31,36)$. In rodents, hypophysectomy causes a peripheral anemia (7), whereas in dogs, monkeys $(36)$, and man $(8,31)$ the impaired erythropoiesis is associated with a parallel decrease in plasma volume, so that hemoglobin concentration and hematocrit remain relatively constant or are only moderately reduced (13). Patients with $\mathrm{GH}$ deficiency exhibited diminished red cell volume and plasma volume to a degree comparable with patients with panhypopituitarism (31).

In this context it appeared worthwhile to investigate red cell enzyme activities of growth-retarded patients with and without $\mathrm{GH}$ deficiency before and after $\mathrm{GH}$ administration.

\section{MATERIALS AND METHODS}

A total of 66 subjects was examined: 30 of these were normal control subjects consisting of healthy young adults of both sexes (blood donors and laboratory technicians) (group $N$ ). The remaining were 36 patients with growth retardation aged 5-23 years. Our control group is comparable with this group of patients, since there are no sex differences in red cell enzyme activities known in normal persons. In addition, erythrocyte enzyme activities were compared in our laboratory in normal adults and in normal children aged 
10-14 years and 5-10 years, respectively. Similar red cell enzyme activities were found in all three groups of normal persons.

All patients with growth retardation underwent detailed physical and laboratory examination. To evaluate $\mathrm{GH}$ secretion, $\mathrm{GH}$ response to insulin-induced hypoglycemia and arginine infusion was investigated. Thyroid-stimulating hormone was evaluated indirectly by determination of thyroid ${ }^{132}$ I uptake and by measurement of serum protein-bound iodine. In the assessment of ACTH secretion the oral 2-day Metyrapone test and the ACTH-infusion test were employed. As a rough screening test for adiuretin deficiency the specific gravity was repeatedly measured in the first urine portion in the morning.

In 21 of the 36 patients with short stature, GH deficiency was established (group I, aged 5-23 years). The mean maximum GH response to insulin-induced hypoglycemia was $1.195 \mathrm{ng} / \mathrm{ml} \pm$ $0.173(\mathrm{SEM})$ and to arginine infusion $1.314 \mathrm{ng} / \mathrm{ml} \pm 0.203(\mathrm{SEM})$. Ten of these 21 patients were suffering from isolated $\mathrm{GH}$ deficiency. However, the definite diagnosis of an isolated $\mathrm{GH}$ deficiency must await the appearance of puberty. In 3 of the 10 patients puberty had already begun and the remaining 7 patients could not have gone into puberty considering their retarded bone age.

In the remaining 15 of the 36 patients with growth retardation, a GH deficiency was excluded (group $I I$, aged 5-17 years). The mean maximum $\mathrm{GH}$ response to insulin-induced hypoglycemia was $17.10 \mathrm{ng} / \mathrm{ml} \pm 2.32(\mathrm{SEM})$ and to arginine infusion 13.68 $\mathrm{ng} / \mathrm{ml} \pm 2.94(\mathrm{SEM})$. The remaining tests evaluating hypothalamic and pituitary function likewise revealed no endocrine disease in this group with the exception of two patients in whom a moderate hypothyroidism was found. In both patients appropriate thyroid hormone medication had already been started a long time before our investigations so that these patients were euthyroid when studied. The group of the remaining 13 growth-retarded patients without $\mathrm{GH}$ deficiency included 5 children with constitutional delay in growth and sexual maturation, 4 patients with familial short stature, 3 patients with familial short stature combined with constitutional delay in growth and sexual maturation, and 1 patient with Russell-Silver-syndrome.

Before and after GH therapy blood was obtained for estimation of erythrocyte count, hemoglobin concentration, hematocrit, reticulocyte count, and red cell enzyme activities. All 36 patients were treated daily with $2 \mathrm{mg}$ human growth hormone intramuscularly for 7 days. Human growth hormone was commercially obtained and prepared by the Roos method with a potency of $2 \mathrm{IU} / \mathrm{mg}$ (38). Some metabolic effects of this $\mathrm{GH}$ preparation have recently been investigated by two of us $(N S, W B)$ in growth-retarded children with and without $\mathrm{GH}$ deficiency (32). This hormone preparation has been successfully used in the treatment of all of our 23 hypopituitary dwarfs.

GH was determined by the double antibody radioimmunoassay method (26). The lower limit of sensitivity of this assay in our laboratory is $0.5 \mathrm{ng} / \mathrm{ml}$. Routine hematologic studies were performed by standard methods. Activities of 15 red cell enzymes were assayed: hexokinase, phosphoglucomutase, glucose phosphate isomerase, phosphof ructokinase, fructose diphosphate aldolase, glyceraldehyde-3 -phosphate dehydrogenase, triosephosphate isomerase, 2,3-diphosphoglycerate mutase, 3-phosphoglycerate kinase, 3-phosphoglycerate mutase, enolase, pyruvate kinase, glucose-6-phosphate dehydrogenase, 6-phosphogluconic dehydrogenase, and glutathione reductase. The activity of these erythrocyte enzymes was measured spectrophotometrically at $37^{\circ}$ in hemolyzed red cells. The assay procedures for all red cell enzymes have been previously reported (30).

\section{STATISTICAL EVALUATION}

Bartlett's test for homogeneity of variance was performed before tests concerning the difference of two means. According to these results nonparametric tests (the Mann-Whitney U-test for inde- pendent samples and the Wilcoxon sign-rank test for correlated data) or the one-tailed $t$-test were carried out (5). Investigations in animals and man $(3,4,7,8,11,13,15,16,23,24,28,31,36)$ produced convincing evidence justifying a one-tailed test $(6,29)$. Since results of enzyme activity assays were not available in every patient, sample size of data was different. Furthermore, a result was taken into account only when the enzyme activity of a simultaneously assayed control was within the range of a normal sample. These conditions resulted in a reduction of sample size in some erythrocyte enzymes.

\section{RESULTS}

\section{HEMATOLOGIC DATA}

Before GH treatment there was no significant difference between the mean values of erythrocyte count, hematocrit, hemoglobin concentration, and reticulocyte count in group $I$ (GH deficiency) and group $I I$ (no GH deficiency). With GH therapy no significant change of erythrocyte count, hemoglobin concentration or hematocrit was observed in group $I$ and $I I$. However, after GH administration reticulocyte count was significantly increased in both groups of patients: in group I mean pretreatment value was $1.294 \% \pm 0.084(\mathrm{SEM})$, mean post-treatment value $2.081 \% \pm$ 0.287 (SEM), $P<0.005$. In group $I I$ mean pretreatment value was $1.0 \% \pm 0.184$ (SEM), mean post-treatment value $1.407 \%$ \pm 0.193 (SEM), $P<0.01$. Our data indicate that $\mathrm{GH}$ treatment induced a significant increase in reticulocyte count in both groups of patients with short stature.

\section{PRETREATMENT ENZYME ACTIVITIES IN GROUP II AND $I I$ COMPARED WITH THOSE IN NORMAL CONTROL SUBJECTS (GROUP $N)$}

There was no significant difference between the mean pretreatment erythrocyte enzyme activities in group $I I$ (no GH deficiency) and the enzyme activities in normal control subjects (group $N$ ). In GH-deficient patients (group $I$ ) the mean pretreatment activities in 5 out of 15 erythrocyte enzymes were significantly below the range obtained in the control group (glucose phosphate isomerase, triosephosphate isomerase, glyceraldehyde-3-phosphate dehydrogenase, 2,3-diphosphoglycerate mutase, 3-phosphoglycerate kinase). The reduction in one further red cell enzyme activity (3-phosphoglycerate mutase) was statistically not significant (Fig. $1)$.

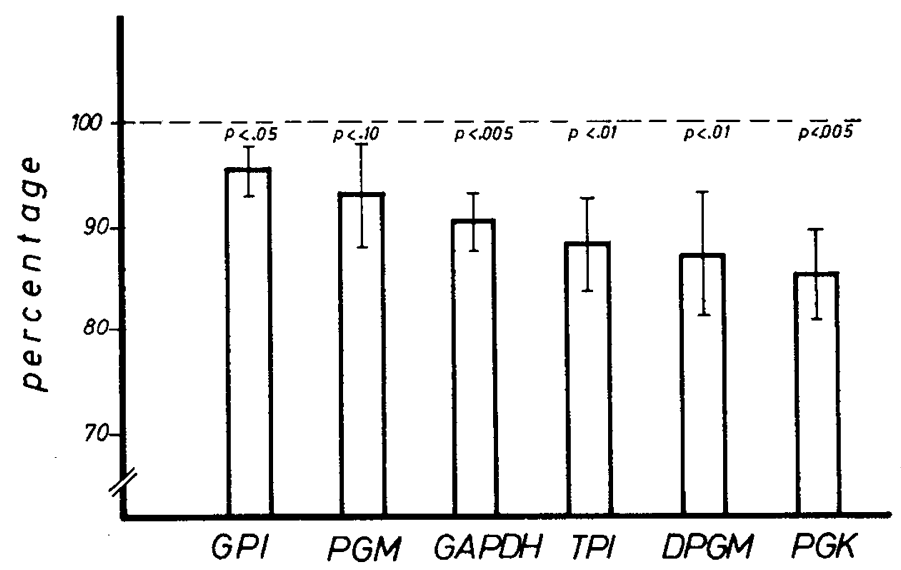

Fig. 1. Decreased pretreatment activities of erythrocyte enzymes (mean $\pm \mathrm{SEM}$ ) in growth hormone-deficient patients (expressed as percentage of activities in normal control subjects). $G P I$ : glucose phosphate isomerase; $P G M$ : 3-phosphoglycerate mutase; $G A P D H$ : glyceraldehyde-3-phosphate dehydrogenase; $T P I$ : triosephosphate isomerase; $D P G M:$ 2,3-diphosphoglycerate mutase; $P G K$ : 3-phosphoglycerate kinase. 
CHANGES IN ERYTHROCYTE ENZYME ACTIVITY IN GROUP I AND $I I$ WITH GH THERAPY

With GH therapy seven enzyme activities (phosphoglucomutase, fructose diphosphate aldolase, 6-phosphogluconic dehydrogenase, glutathione reductase, glyceraldehyde-3-phosphate dehydrogenase, phosphofructokinase, 3-phosphoglycerate kinase) showed no significant increase. In eight erythrocyte enzyme activities a significant increase was induced by $\mathrm{GH}$ treatment, one of them (hexokinase) significantly rising in both groups of growth-retarded patients. The remaining seven red cell enzymes showed significantly elevated activities only in patients lacking GH (3-phosphoglycerate mutase, glucose phosphate isomerase, triosephosphate isomerase, 2,3-diphosphoglycerate mutase, enolase, pyruvate kinase, glucose-6-phosphate dehydrogenase) (Table 1, Fig. 2).

Table 1. Activity of erythrocyte enzymes before and after growth hormone treatment

\begin{tabular}{|c|c|c|c|}
\hline Enzyme $^{1}$ & $\begin{array}{l}\text { Pretreatment } \\
\text { activity }^{2}\end{array}$ & $\begin{array}{l}\text { Post-treatment } \\
\text { activity }\end{array}$ & $P^{3}$ \\
\hline \multicolumn{4}{|c|}{ 1. No significant increase after growth hormone therapy } \\
\hline \multicolumn{4}{|c|}{ PGLUC } \\
\hline I & $\begin{array}{l}5.151 \pm 0.185 \\
(16)\end{array}$ & $\begin{array}{l}4.843 \pm 0.185 \\
(16)\end{array}$ & n.s. \\
\hline H & $\begin{array}{l}5.333 \pm 0.518 \\
(14)\end{array}$ & $\begin{array}{l}5.364 \pm 0.590 \\
\text { (14) }\end{array}$ & n.s. \\
\hline \multicolumn{4}{|l|}{ ALD } \\
\hline I & $\begin{array}{l}7.372 \pm 0.344 \\
(20)\end{array}$ & $\begin{array}{c}7.216 \pm 0.274 \\
(20)\end{array}$ & n.s. \\
\hline II & $\begin{array}{l}7.345 \pm 0.413 \\
\quad(15)\end{array}$ & $\begin{array}{l}7.708 \pm 0.487 \\
(15)\end{array}$ & n.s. \\
\hline \multicolumn{4}{|l|}{ 6-PGD } \\
\hline I & $\begin{array}{l}9.799 \pm 0.417 \\
\quad(18)\end{array}$ & $\begin{array}{c}10.569 \pm 0.590 \\
\text { (18) }\end{array}$ & n.s. \\
\hline II & $\begin{array}{c}10.481 \pm 0.808 \\
(14)\end{array}$ & $\begin{array}{c}11.238 \pm 0.817 \\
\text { (14) }\end{array}$ & n.s. \\
\hline \multicolumn{4}{|c|}{ (II) } \\
\hline I & $\begin{array}{l}9.236 \pm 0.398 \\
(14)\end{array}$ & $\begin{array}{l}9.56 \pm 0.608 \\
(14)\end{array}$ & n.s. \\
\hline II & $\begin{array}{l}10.542 \pm 0.633 \\
\quad(14)\end{array}$ & $\begin{array}{l}11.149 \pm 0.702 \\
(14)\end{array}$ & n.s. \\
\hline \multicolumn{4}{|l|}{ GAPDH } \\
\hline I & $\begin{array}{c}205.601 \pm 6.436 \\
(18)\end{array}$ & $\begin{array}{c}201.761 \pm 8.043 \\
(18)\end{array}$ & $\mathrm{n}, \mathrm{s}$. \\
\hline II & $\begin{array}{l}223.09 \pm 11.831 \\
\quad(13)\end{array}$ & $\begin{array}{l}233.609 \pm 17.207 \\
\text { (13) }\end{array}$ & n.s. \\
\hline \multicolumn{4}{|l|}{ PFK } \\
\hline I & $\begin{array}{c}22.223 \pm 0.943 \\
(15)\end{array}$ & $\begin{array}{l}24.926 \pm 2.206 \\
(15)\end{array}$ & n.s. \\
\hline II & $\begin{array}{l}20.899 \pm 1.436 \\
\quad(11)\end{array}$ & $\begin{array}{l}22.938 \pm 1.110 \\
(11)\end{array}$ & n.s. \\
\hline \multicolumn{4}{|l|}{ PGK } \\
\hline I & $\begin{array}{c}109.817 \pm 6.701 \\
(15)\end{array}$ & $\begin{array}{c}128.566 \pm 8.520 \\
(15)\end{array}$ & n.s. \\
\hline II & $\begin{array}{c}118.665 \pm 12.197 \\
\text { (11) }\end{array}$ & $\begin{array}{c}121.972 \pm 6.993 \\
(11)\end{array}$ & n.s. \\
\hline \multicolumn{4}{|c|}{$\begin{array}{l}\text { 2. Significant increase with growth hormone therapy } \\
\qquad \begin{array}{l}\text { a. In group I and II }\end{array}\end{array}$} \\
\hline HK & & & \\
\hline I & $\begin{array}{l}1.049 \pm 0.063 \\
\text { (14) }\end{array}$ & $\begin{array}{l}1.286 \pm 0.107 \\
\quad(14)\end{array}$ & $<0.025$ \\
\hline II & $\begin{array}{l}1.069 \pm 0.090 \\
\quad(14)\end{array}$ & $\begin{array}{l}1.249 \pm 0.081 \\
(14)\end{array}$ & $<0.025$ \\
\hline \multicolumn{4}{|c|}{ b. Only in group I } \\
\hline$\underset{1}{P G M}$ & $60.641 \pm 3.781$ & $66.755+2640$ & $<005$ \\
\hline & $\begin{array}{c}0.041 \pm 3.101 \\
(17)\end{array}$ & $\begin{array}{c}00.135 \pm 2.040 \\
(17)\end{array}$ & $<0.05$ \\
\hline II & $\begin{array}{c}64.725 \pm 3.178 \\
(15)\end{array}$ & $\begin{array}{c}69.405 \pm 3.495 \\
(15)\end{array}$ & n.s. \\
\hline
\end{tabular}

\begin{tabular}{|c|c|c|c|}
\hline Enzyme $^{1}$ & $\begin{array}{l}\text { Pretreatment } \\
\text { activity }^{2}\end{array}$ & $\begin{array}{l}\text { Post-treatment } \\
\text { activity }\end{array}$ & $P^{3}$ \\
\hline \multicolumn{4}{|l|}{ GPI } \\
\hline I & $\begin{array}{c}42.445 \pm 1.028 \\
(14)\end{array}$ & $\begin{array}{c}45.996 \pm 1.801 \\
(14)\end{array}$ & $<0.025$ \\
\hline II & $\begin{array}{c}46.851 \pm 2.859 \\
(14)\end{array}$ & $\begin{array}{l}47.77 \pm 2.540 \\
\text { (14) }\end{array}$ & n.s. \\
\hline \multicolumn{4}{|l|}{ TPI } \\
\hline I & $\begin{array}{c}1,895.875 \pm 118.536 \\
(16)\end{array}$ & $\begin{array}{c}2,255.188 \pm 115.099 \\
(16)\end{array}$ & $<0.025$ \\
\hline II & $\begin{array}{c}2,223.923 \pm 113.848 \\
(13)\end{array}$ & $\begin{array}{c}2,145.077 \pm 148.006 \\
(13)\end{array}$ & n.s. \\
\hline \multicolumn{4}{|l|}{ DPGM } \\
\hline I & $\begin{array}{l}3.404 \pm 0.221 \\
(16)\end{array}$ & $\begin{array}{l}3.989 \pm 0.302 \\
(16)\end{array}$ & $<0.05$ \\
\hline II & $\begin{array}{l}3.833 \pm 0.184 \\
(12)\end{array}$ & $\begin{array}{l}3.408 \pm 0.508 \\
\quad(12)\end{array}$ & n.s. \\
\hline \multicolumn{4}{|c|}{. } \\
\hline I & $\begin{array}{c}16.614 \pm 0.592 \\
(17)\end{array}$ & $\begin{array}{c}18.435 \pm 0.976 \\
(17)\end{array}$ & $<0.05$ \\
\hline II & $\begin{array}{c}17.287 \pm 0.821 \\
(14)\end{array}$ & $\begin{array}{c}18.369 \pm 1.222 \\
(14)\end{array}$ & n.s. \\
\hline \multicolumn{4}{|c|}{ (12) } \\
\hline I & $\begin{array}{c}19.708 \pm 0.643 \\
(13)\end{array}$ & $\begin{array}{c}22.438 \pm 1.379 \\
(13)\end{array}$ & 0.05 \\
\hline II & $\begin{array}{c}20.058 \pm 1.094 \\
(12)\end{array}$ & $\begin{array}{l}21.66 \pm 1.541 \\
\quad(12)\end{array}$ & n.s. \\
\hline \multicolumn{4}{|l|}{ G6PD } \\
\hline I & $\begin{array}{c}11.693 \pm 0.441 \\
(17)\end{array}$ & $\begin{array}{l}12.709 \pm 0.598 \\
(17)\end{array}$ & $<0.05$ \\
\hline II & $\begin{array}{c}12.262 \pm 0.892 \\
\text { (13) }\end{array}$ & $\begin{array}{l}12.552 \pm 0.855 \\
(13)\end{array}$ & n.s. \\
\hline
\end{tabular}

${ }^{1}$ PGLUC: phosphoglucomutase; ALD: fructose diphosphate aldolase; 6-PGD: 6-phosphogluconic dehydrogenase; GR: glutathione reductase; GAPDH: glyceraldehyde-3-phosphate dehydrogenase; PFK: phosphofructokinase; PGK: 3-phosphoglycerate kinase; HK: hexokinase; PGM: 3-phosphoglycerate mutase; GPI: glucose phosphate isomerase; TPI: triosephosphate isomerase; DPGM: 2,3-diphosphoglycerate mutase; EN: enolase; PK: pyruvate kinase; G6PD: glucose-6-phosphate dehydrogenase; group I: growth hormone-deficient patients; group II: patients with short stature without growth hormone deficiency.

${ }^{2}$ Micromoles of substrate utilized per min per $\mathrm{g}$ hemoglobin. Values are means \pm SEM. Sample size is shown in parentheses.

${ }^{3}$ Significance level of differences in means. n.s.: not significant.

POST-TREATMENT ENZYME ACTIVITIES IN GROUP I AND $I I$ COMPARED WITH THOSE IN NORMAL CONTROLS (GROUP $N$ )

In $\mathrm{GH}$-deficient patients the mean post-treatment activities of three red cell enzymes were significantly elevated above the range obtained in the normal control group: hexokinase $(P<0.01)$, enolase $(P<0.05)$, and glucose-6-phosphate dehydrogenase $(P=$ 0.025 ). One red cell enzyme remained significantly below the control value: glyceraldehyde-3-phosphate dehydrogenase $(P<$ 0.005 ). In group II (no GH deficiency) only one red cell enzyme activity was significantly increased above the control value after $\mathrm{GH}$ treatment; this was hexokinase $(P<0.005)$.

\section{DISCUSSION}

An elevated activity of one erythrocyte enzyme (glucose-6-phosphate dehydrogenase) during $\mathrm{GH}$ therapy of hypopituitary dwarfs had been reported previously $(4,28)$. Our study showed a significant increase in 8 of 15 investigated red cell enzyme activities after $\mathrm{GH}$ treatment in patients lacking $\mathrm{GH}$; in three of these enzymes the increase was significantly above the control value. It is apparent that activities of erythrocyte enzymes which were reduced significantly in GH-deficient patients before therapy increased 


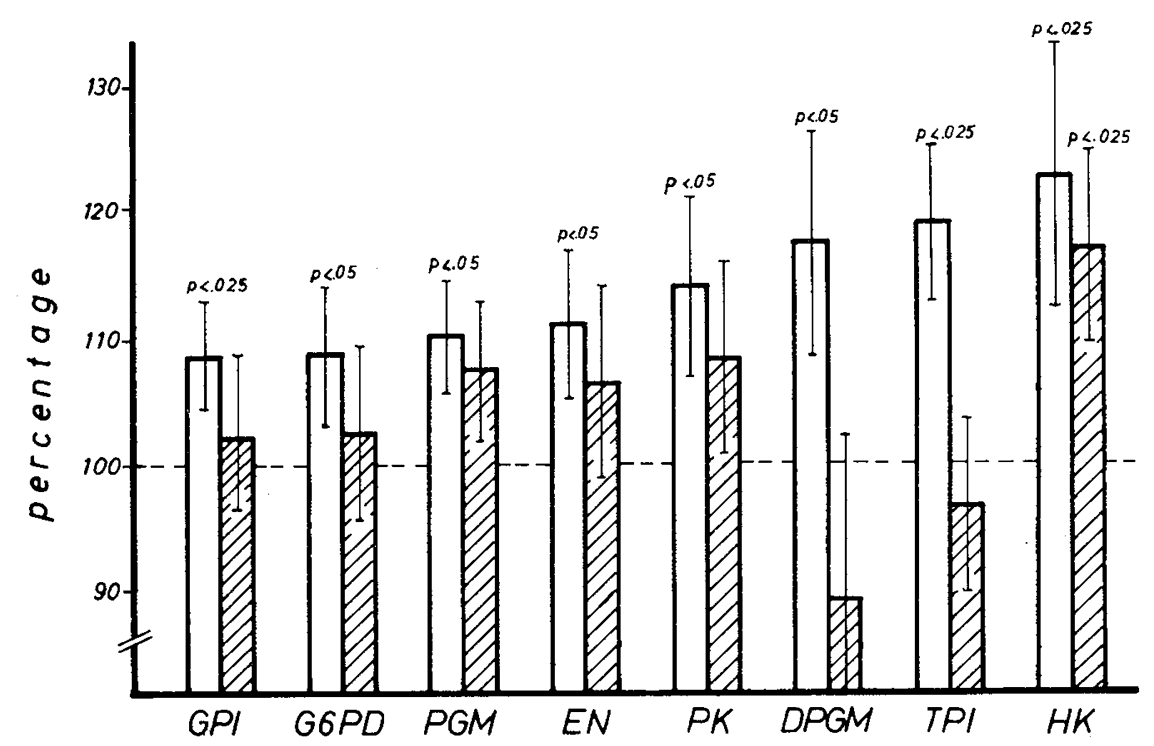

Fig. 2. Significantly increased erythrocyte enzyme activities after growth hormone treatment. Enzyme activities (mean \pm SEM) expressed as percentage of pretreatment activity. Hatched columns represent patients with short stature without growth hormone deficiency, clear columns represent growth hormone-lacking patients. GPI: glucose phosphate isomerase; G6PD: glucose-6-phosphate dehydrogenase; PGM: 3-phosphoglycerate mutase; $E N$ : enolase; $P K$ : pyruvate kinase; DPGM: 2,3-diphosphoglycerate mutase; TPI: triosephosphate isomerase; $H K$ : hexokinase.

significantly during GH treatment with two exceptions: the increase in 3-phosphoglycerate kinase was statistically not significant and glyceraldehyde-3-phosphate dehydrogenase remained significantly reduced after $\mathrm{GH}$ treatment. In patients without $\mathrm{GH}$ deficiency one red cell enzyme activity showed a significant increase due to $\mathrm{GH}$ administration; this enzyme activity was significantly elevated above the control value. The difference in the effect of $\mathrm{GH}$ treatment in both groups of patients can be explained by the known fact that patients lacking $\mathrm{GH}$ show a much stronger response to this hormone than do normal individuals (25). As GH therapy results in a proportional rise in plasma volume (27), the hemoglobin concentration and hematocrit showed no significant alteration in our patients during $\mathrm{GH}$ treatment.

In two laboratories GH showed an inhibitory effect on glucose consumption by erythrocytes in vitro, the activity of phosphofructokinase was decreased $(19,22)$. However, these observations were not confirmed by extended studies in another laboratory (33). In addition, the results of these in vitro studies cannot be compared with our results, since the $\mathrm{GH}$ concentrations in vitro were much higher than the concentrations achieved in our patients during $\mathrm{GH}$ treatment.

The reduced pretreatment activities of six erythrocyte enzymes in patients lacking GH might be due to red cell aging. Enzyme studies have shown that the activity level of several erythrocyte enzymes progressively decreases with age. This metabolic deficiency results in structural and functional alterations of the erythrocyte, finally causing its lysis $(10,20)$. From the 60 th day of red cell lifespan there is a progressive decrease of phosphorylated compounds, especially of ATP (17). Four of the five enzymes showing significantly reduced pretreatment activity in GH-deficient patients are among those red cell enzymes for which activity declined with age: glucose phosphate isomerase $(1,10,20)$, triosephosphate isomerase $(10,18)$, glyceraldehyde-3-phosphate dehydrogenase $(1,10,18)$, and 3-phosphoglycerate kinase $(10,18)$. Glyceraldehyde 3-phosphate dehydrogenase activity, in particular, diminishes very quickly with age, having a half-time of 34 days (17). Moreover, in one patient with "true medullary aplasia," an abnormal low activity of 2,3-diphosphoglycerate mutase was found (2). However, whether the decreased activity of some red cell enzymes in patients lacking GH before therapy suggests the presence of a relatively aged red cell population is open to question. Only a substantially prolonged red cell lifespan would result in reduced erythrocyte enzyme activities. However, to elucidate this question, one would have to study red cell lifespan by methods using radioactive compounds. For ethical reasons we did not perform such studies.

The increase in red cell enzyme activities induced by GH cannot be due to an activation of pre-existing enzyme molecules, since $\mathrm{GH}$ added to erythrocytes in vitro did not increase red cell enzyme activities (4). It is well established that several glycolytic enzymes are present at a higher activity level in younger red cells. This is true of those enzymes which also had higher levels in our patients after GH therapy: hexokinase $(14,35,37), 3$-phosphoglycerate mutase $(14,34)$, glucose phosphate isomerase $(14,34)$, triosephosphate isomerase $(14,34)$, enolase $(14,34)$, pyruvate kinase $(14,34$, $35,37)$, glucose 6-phosphate dehydrogenase $(14,34,35,37)$, and phosphofructokinase $(14,34)$. A moderately elevated activity was also found in 3-phosphoglycerate kinase (14). In our patients the greatest increase in activity was exhibited by hexokinase, the rate-limiting enzyme of glycolysis $(10,17)$. It was also the only enzyme activity which rose significantly in both groups of patients. It may be assumed that $\mathrm{GH}$ therapy in our patients stimulated erythropoiesis resulting in a red cell population with a younger mean cell age. The observed rise of reticulocytes is in support of this explanation of our results after GH treatment.

These findings are in agreement with studies in hypophysectomized animals $(7,11,24,36)$ and a recent study in hypopituitary patients (13) demonstrating an erythropoietic effect of $\mathrm{GH}$.

Two mechanisms of $\mathrm{GH}$ action on erythropoiesis are discussed: an indirect and a direct stimulatory effect on red cell production. In animals and man hypophysectomy induces a decrease in oxygen consumption $(7,8)$. Therefore it was concluded that GH influences erythropoiesis by increasing the oxygen need of the tissues. Recent studies have indicated that $\mathrm{GH}$ acts through increased erythropoietin (12) production $(21,24,3 I, 36)$. However, GH exerts its erythropoietic effect by also affecting the bone marrow directly (9).

Whether GH in our patients in addition to stimulation of erythropoiesis also induced an increased enzyme synthesis in the bone marrow is open to question. Elevated enzyme activities due to de novo synthesis of the enzyme protein after $\mathrm{GH}$ administration have been reported $(16,23)$. Judging from a previous study $(35)$, the observed rise of hexokinase activity correlates approximately to the rise of reticulocyte count and may thus be fully explained by the erythropoietic action of GH. However, the possibility that GH also exerted a direct stimulatory effect on nucleated red cell enzyme synthesis cannot definitively be excluded. 


\section{SUMMARY}

The effect of $\mathrm{GH}$ on 15 erythrocyte enzyme activities was investigated in 36 growth-retarded patients with and without GH deficiency. Before $\mathrm{GH}$ administration the activity was significantly lower in five red cell enzymes in patients lacking GH compared with the activity obtained in 30 normal control subjects. GH treatment resulted in a significant increase in eight red cell enzyme activities in patients with GH deficiency, and increase in one erythrocyte enzyme activity in patients without $\mathrm{GH}$ deficiency. The elevation of enzyme activities after GH treatment was associated with a significant increase in reticulocyte count in patients with and without $\mathrm{GH}$ deficiency.

\section{REFERENCES AND NOTES}

1. Blum, K. U.: Blutzellen als Indikatoren von Stoffweschsel-störungen. Z. Klin. Chem. Klin. Biochem., 5: 226 (1967).

2. Boivin, P., Galand, C., and Audollent, M.: Erythroenzymopathies acquises. I Anomalies quantitatives observées dans 100 cas d'hémopathies diverses. Pathol. Biol. 18: 175 (1970).

3. Bozzini, C. E.: Decrease in the number of erythrogenic elements in the blood-forming tissues as the cause of anemia in hypophysectomized rats. Endocrinology, 77: 977 (1965).

4. Butenandt, O.: Der Einfluss von humanem Wachstumshormon auf Erythrocytenfermente bei minderwüchsigen Kindern. Mschr. Kinderheilk., /18: 238 (1970)

5. Clauss, G., and Ebner, H.: Grundlagen der Statistik für Psychologen, Pädagogen und Soziologen (Verlag Harri Deutsch, Zürich, 1972).

6. Colton, T.: Statistics in Medicine (Little, Brown and Co., Boston, 1974).

7. Crafts, R. C., and Meineke, H. A.: The anemia of hypophysectomized animals. Ann. N. Y. Acad. Sci., 77: 501 (1959).

8. Falkheden, T., Sjögren, B., and Westiing, H.: Studies on the blood volume following hypophysectomy in man. Acta Endocrinol., 42: 522 (1963).

9. Fisher, J. W., Roh, B. L., Couch, C., and Nightingale, W. O.: Influence of cobalt, sheep erythropoietin and several hormones on erythropoiesis in bone marrows of isolated perfused hind limbs of dogs. Blood, 23: 87 (1964).

10. Fornaini, G.: Biochemical modifications during the life span of the erythrocyte. Ital. J. Biochem., 16: 257 (1967).

11. Fruhman, G. J., and Gordon, A. S.: Effects of growth hormone and cortisol upon hemopoiesis. Acta Haematol. 15: 249 (1956).

12. Gordon, A. S.: Annotation: The current status of erythropoietin. Brit. J. Haematol., 21: 611 (1971)

13. Jepson, J. H., and McGarry, E. E.: Hemopoiesis in pituitary dwarfs treated with human growth hormone and testosterone. Blood, 39: 238 (1972).

14. Konrad, P. N., Valentine, W. N., and Paglia, D. E.: Enzymatic activities and glutathione content of erythrocytes in the newborn: Comparison with red cells of older normal subjects and those with comparable reticulocytosis. Acta Haematol., 48: 193 (1972).

15. Korner, A.: Growth hormone control of biosynthesis of protein and ribonucleic acid. Rec. Progr. Horm. Res. 21: 205 (1965).

16. Korner, A., and Hogan, B. L. M.: The effect of growth hormone on inducible liver enzymes. In: A. Pecile and E. E. Müller: Growth and Growth Hormone, p. 98 (Excerpta Medica, International Congress Series No. 244, Amsterdam, 1972).

17. Löhr, G. W., and Waller, H. D.: Zur Biochemie der Erythrocytenalterung. Fol. Haematol. (Leipzig), 78: 385 (1962).

18. Löhr, G. W., Waller, H. D., Karges, O., Schlegel, B., and Müller, A. A.: Zur Biochemie der Alterung menschlicher Erythrocyten. Klin. Wschr., 21: 1008 (1958).

19. Ludescher, E., and Hohenwallner, W.: Der Einfluss von menschlichem Wach- stumshormon auf die Glykolyse im menschlichen Erythrocyten in vitro. Clin. Chim. Acta, 24: 423 (1969).

20. Marks, P. A., Johnson, A. B., and Hirschberg, E.: Effect of age on the enzyme activity in erythrocytes. Proc. Nat. Acad. Sci., 44: 529 (1958).

21. Meineke, H. A., and Crafts. R. C.: Further observations on the mechanism by which androgens and growth hormone influence erythropoiesis. Ann. N. Y. Acad. Sci., 149: 298 (1968).

22. Oski, F. A., Root, A., and Winegrad, A. I.: In vitro inhibition of erythrocyte glucose consumption by human growth hormone. Nature, 215: 81 (1967).

23. Ottolenghi, C., and Cavagna, R.: Effect of hypophyseal growth hormone on the activity of tyrosine transaminase of the isolated perfused rat liver. Endocrinology, 83: 924 (1968).

24. Peschle, C., Rappaport, I. A., Sassa, G. F., Gordon, A. S., and Condorelli, M. Mechanism of growth hormone $(\mathrm{GH})$ action on erythropoiesis. Endocrinology, 91: 511 (1972).

25. Prader, A., Illig, R., Széky, J., and Wagner, H.: The effect of human growth hormone in hypopituitary dwarfism. Arch. Dis. Childhood, 39: 535 (1964).

26. Quabbe, H. J.: Radioimmunologische Bestimmung von Wachstumshormon im Plasma des Menschen. Z. Klin. Chem. Klin. Biochem., 7: 259 (1969).

27. Rodriguez, J. M., and Shahidi, N. T.: Erythrocyte 2,3-diphosphoglycerate in adaptive red-cell-volume deficiency. N. Engl. J. Med., 285: 479 (1971)

28. Root, A. W. Oski, F. A., Bongiovanni, A. M., and Eberlein, W. R.: Erythrocyte glucose-6-phosphate dehydrogenase activity in children with hypothyroidism and hypopituitarism. J. Pediat., 70: 369 (1967).

29. Sachs, L.: Angewandte Statistik, Ed. 4 (Springer-Verlag, New York, 1974).

30. Schröter, W.: Transitorischer Pyruvatkinase- und Glutathionreductase-Mangel der Erythrocyten bei chronischer idiopathischer infantiler Pancytopenie. Klin. Wschr., 48: 1407 (1970).

31. Shahidi, N. T., Vitale, L. F. Desai, J. N., Rao, L. M., Kerr, G. R., and Tuffli, G. A.: Blood volume and erythrocyte 2,3-diphosphoglycerate in growth hormone deficiency. In: Advances in Human Growth Hormone Research, p. 920, Symposium, October 1973, Baltimore (United States Department of Health, Education and Welfare NIH publication no. 74-612, 1973).

32. Stahnke, N., Menking, M., Rybak, Ch., and Blunck, W.: Short-term response of plasma amino acids to HGH. Acta Endocrinol. Suppl., 173: 98 (1973).

33. Tanser, C., and de Leeuw, N. K. M.: Failure of human growth hormone and human placental lactogen to affect glucose consumption by human erythrocytes and leukocytes in vitro. Can. J. Physiol. Pharmacol., 50: 1014 (1972)

34. Valentin, W. N., Konrad, P. N., and Paglia, D. E.: Dyserythropoiesis, refractory anemia, and "preleukemia": Metabolic features of the erythrocytes. Blood, 41 : 857 (1973).

35. Valentine, W. N., Oski, F. A., Paglia, D. E., Baughan, M. A., Schneider, A. S., and Naiman, J. L.: Hereditary hemolytic anemia with hexokinase deficiency. N. Engl. J. Med., 276: I (1967).

36. Vitale, L., Shahidi, N. T., Kerr, G. E., Wolf, R. C., Korst, D. R. and Meyer, R. $\mathrm{K} .:$ The role of growth hormone and thyroxin in erythropoietic restoration in hypophysectomized monkeys. Proc. Soc. Exp. Biol. Med., 138: 418 (1971).

37. Witt, I., Herdan, M., and Künzer, W.: Vergleichende Untersuchungen von Enzymaktivitäten in Retikulocyten-reichen und Retikulocyten-armen Fraktionen aus Neugeborenen- und Erwachsenenblut. Klin. Wschr., 6: 149 (1968).

38. "Crescormon," Deutsche Kabi GmbH, München, West Germany.

39. Some findings of this study were presented at the Ninth Acta Endocrinologica Congress, June 1973, Oslo. Norway.

40. This work was supported by the Deutsche Forschungsgemeinschaft, Sonderforschungsbereich SFB 34:Endokrinologie, and grant Schr 86/11, Bonn-Bad Godesberg, West Germany.

41. The authors thank Ms. W. Kalinowsky, Mrs. A. Steinberg, and Ms. J. Trautmann for expert technical assistance and Dr. med. Dipl.-Psych. H. C. Steinhausen for statistical advice.

42. The present address of Dr. W. Blunck is: Children's Hospital Altona, Bleickenallee 38, 2 Hamburg 50 (West Germany).

43. Requests for reprints should be addressed to: N. Stahnke, M.D., Universitaetskinderklinik, Martinistr. 52, 2 Hamburg 20 (West Germany).

44. Accepted for publication April 9, 1976. 